

\section{INTRODUÇÃO CONCEITUAL}

Essa interrogação, que nos fazemos também, foi feita por um funcionário do Immigration and Naturalization Service (INS), organismo do governo americano responsável pela execução da política de imigração e pela apreensão dos estrangeiros ilegais. Embora a frase tenha sido dita nos anos 70, período de intenso desenvolvimento econômico no Brasil, ela demonstra que já nessa ocasião os brasileiros incomodavam as autoridades, constituindo um dos inúmeros fluxos de imigrantes do terceiro mundo que procuram abrigo e uma vida melhor nos Estados Unidos.

Este artigo, no entanto, pretende focalizar a atenção nos anos 80 , quando o fenômeno se torna muito mais significativo. No país "doador", o Brasil, a chamada "década perdida" e nos EUA, país receptor, a "era Reagan", de intenso crescimento econômico. Apesar de que tentaremos mostrar mais adiante que o diferencial de renda entre as economias sub e desenvolvida não é o fulcro da questão migratória, pensamos que a conjuga-

Hoje, os interesses primordiais dos Estados Unidos, tanto no plano político, quanto no econômico e no intelectual, não incluem o Brasil e a América Latina.

ção da estagnação econômica aqui com o grande crescimento lá estão relacionados com o grande crescimento da emigração dos brasileiros.

Os anos 80 assistiram, por um lado, ao processo de redemocratização na América Latina e também no bloco socialista, acompanhado de um gradual descongelamento das relaçōes conflitivas entre as duas superpotências, líderes dos dois antigos blocos mundiais. $\mathrm{Na}$ segunda metade da década, alguns brasilianistas (categoria de investigadores que aparece no fim dos anos 60 e se multiplica, assim como suas obras, nos anos 70) ainda se preocupavam com os diferentes modos de liberalização dos regimes políticos na América do Sul.

Hoje, os interesses primordiais dos Estados Unidos, tanto no plano político, quanto no econômico e intelectual, não incluem o Brasil e a América Latina. Estes perderam interesse em todos esses planos, dada a enorme atração representada pela liberalização da Europa do Leste, pela unificação alemã, pelo fim da guerra fria e pelo fortalecimento político e econômico da comunidade européia, assim como dos "tigres asiáticos".

Há vários sintomas dessa mudança completa de rumos. Os investimentos americanos estão se dirigindo para o Leste Europeu e as verbas destinadas à pesquisa científica também. A imprensa norteamericana, assim como a universidade, privilegia essa parte do mundo e os scholars dessa região estão em todo o país.

Todas essas modificações, brevemente delineadas acima, reduziram sensivelmente a preocupação do mundo acadêmico americano com o Brasil. Hoje, a universidade e a sociedade americanas esqueceram o "gigante adormecido", que só é lembrado na imprensa e na opinião pública como um dos maiores devastadores do meio ambiente. O Brasil que a televisão americana põe no ar (raramente) não é mais principalmente o carnaval, o futebol e a sensualidade tropical das mulatas e do samba. A imagem do Brasil hoje, nos Estados Unidos, é a da floresta amazônica queimando. É o tema doentiamente repetido e que difunde uma visão totalmente parcial e distorcida da

1. PIORE, Michael J. Birds of Passage: migrant labor and industrial societies. Cambridge, Cambridge University Press, 1979 . 
2. BARRINGER, Felicity. "State capitals show population gains". New York Times. 26/01/1991, p.10.

3. PIORE, Michael J. Op. cit., p.1. realidade brasileira. Os ambientalistas, que são em geral americanos progressistas, politizados e escolarizados contribuem para a divulgação dessa perspectiva enviesada sobre a participação do Brasil na destruição do meio ambiente. Já recebemos apelos dramáticos, de mestrandos americanos, para "salvar a Amazônia". A condição de brasileiro está fortemente associada à noção de crime ecológico.

Mas existe uma questão, quase desconhecida no Brasil, que começa a chamar a atenção e despertar o interesse nos Estados Unidos, que se enxerga a si mesmo como um melting pot de raças e nacionalidades, a questão dos imigrantes brasileiros. Eles têm se multiplicado de tal maneira nos últimos anos e estão de tal modo dispersos pelo país, que sua presença começa a ser notada como um fenômeno social que merece atenção e esforço analítico. $O$ tema das migrações, historicamente, sempre foi privilegiado nos Estados Unidos, e nos momentos de recessão como o atual, ele desperta atenção redobrada.

A América está sofrendo uma verdadeira invasão de asiáticos, europeus do leste e latino-americanos, entre os quais proporções cada vez maiores de brasileiros: "Mas, enquanto os novos números fornecem uma profunda confirmação de algumas das tendências da década, particularmente o impacto que um afluxo de sete a nove milhões de latino-americanos, asiáticos e europeus tiveram nos Estados Unidos nos anos 80, os demógrafos analisando os números atuais descobriram outras tendências que não tinham sido notadas." 2

Se a esses dados agregarmos algumas estimativas sobre imigrantes clandestinos ou ilegais (como a grande maioria dos brasileiros), a magnitude do problema aparece com maior nitidez: "A maior parte de nossa força de trabalho migrante é clandestina e seu tamanho exato é conseqüentemente desconhecido. Estimativas variam de dois a doze milhões. ${ }^{3}$ Estudos mais recentes que o de Piore, citado acima, indicam que aproximadamente $10 \%$ da força de trabalho dos EUA é composta de estrangeiros ilegais.

Mas, para além da conotação de verdade que os números podem conferir às realidades descritas, a presença dos brasileiros nos EUA "tromba" conosco a todo momento e nas mais diversas cidades e regiões do país. A grande maioria se concentra no eixo New York-New Jersey, a conexão Boston-Governador Valadares é razoavelmente conhecida, assim como o grande número de brasileiros na Flórida.

Mas, eles também estão em outros estados e nas cidades menores: existem colônias de mineiros em Hartford, Bridgeport e Danbury (Connecticut); há uma grande comunidade da cidade de Goiânia vivendo em São Francisco; outras colônias de brasileiros vivem em Denver, assim como em Toronto, no Canadá. Mais adiante cuidaremos de medir com um pouco mais de precisão as dimensões da comunidade brasileira nos Estados Unidos. No momento, pretendemos apenas constatar o fenômeno e enfatizar a inevitabilidade e "agressividade" com que essa presença brasileira atinge o cientista social vivendo nos Estados Unidos.

Quanto à modernidade e importância sócio-política do tema migrações na aldeia cada vez mais global em que estamos vivendo hoje, penso não haver dúvidas. Os brasileiros estão se tornando nos Estados Unidos issues como os turcos na Alemanha, os árabes na França etc. As questões migratórias e os problemas raciais a ela conexos estão preocupando todos os continentes. Os processos migratórios são cada vez mais parte constitutiva da realidade sócio-econômica a nível internacional, num mundo em que uma das macrotendências é a eliminação das fronteiras nacionais e outra é a universalização da in- 
formação e da comunicação.

Nossa intenção é abordar inicialmente de forma genérica o processo migratório brasileiro, descrevendo e analisando suas características principais, inclusive porque o tema ainda não mereceu a devida atenção por parte das ciências sociais brasileiras. O Brasil ainda é considerado um país de imigrantes e é muito pouco conhecido o fato de que ele está se tornando um fornecedor de emigrantes. Numa segunda etapa, pretendemos centrar a atenção no fenômeno da migração de classe média, abordando as motivações e determinantes da evasão de profissionais qualificados que vem ocorrendo especialmente a partir de meados dos anos 80 .

Embora só agora estejamos enfrentando essa problemática, na verdade, ela nos preocupa desde essa ocasião, quando, ministrando um curso de Mestrado na Escola de Administração de Empresas de São Paulo da Fundação Getúlio Vargas, os alunos, em geral de classe média alta, colocaram claramente o desejo profundo de buscar uma melhor qualidade de vida, mais segurança e perspectivas de progresso longe do perene "país do

O consulado brasileiro em

New York avalia por alto em 70.000 o número de brasileiros vivendo só na região de Boston. futuro". As motivações da classe média também têm conotações extraeconômicas, como podemos perceber pelo seguinte depoimento: "Prefiro ser 'proletária', ou classe média baixa aqui nos EUA, do que elite decaida e despossuida lá no Brasil. Por exemplo, lá eu nem precisava de computador porque tinha uma 'serva' secretária que fazia tudo por mim. Aqui, tenho um lap top dos mais baratos. Mas, prefiro depender de mim mesma com meu PC, do que depender da minha 'escrava' até para escrever uma carta". 4

Desde então, nossa sensibilidade sociológica ficou alertada para o problema e passamos a notar que efetivamente muitos estudantes, dentistas, publicitários, jornalistas, cineastas, bibliotecários e outros ramos do setor terciário, especialmente na área de artes e comunicaçōes estavam abandonando o Brasil.

Já nos Estados Unidos ${ }^{5}$, o tema passou a nos "perseguir", como relatamos acima. Realizamos oito longas entrevistas com imigrantes brasileiros e passamos a coletar dados junto às imprensas americana e brasileira. Os casos descritos neste artigo são fruto de entrevistas acompanhadas da "observação participante" junto a duas famílias brasileiras com as quais passamos a conviver. Usamos, portanto, apenas técnicas qualitativas de investigação e apesar de termos tentado uma estimativa aproximada do número de imigrantes brasileiros, o trabalho não tem intenção generalizante, mas apenas de introduzir uma temática nova e relevante para as ciências sociạis.

Quanto à bibliografia e orientação teórica, recorremos a um grupo de estudos interdisciplinar, o Migration and Development Study Group do Center for International Studies do Massachusetts Institute of Technology (M.I.T.), especialmente a obra fascinante do economista Michael Piore. A abordagem desse autor, que informa nosso trabalho, é totalmente heterodoxa e busca confrontar a teoria econômica convencional e agregar variáveis e determinantes sociais e culturais na compreensão dos fenômenos migratórios de longa distância entre áreas subdesenvolvidas e países altamente industrializados.

4. Entrevista de A.B. A maioria dos depoimentos que colhemos não é identificada, porque os depoentes sāo trabalhadores ilegais nos Estados Unidos

5. Fizemos um programa de treinamento noS EUA entre agosto de 1990 e julho de 1992. Inicialmente, como Visiting Scholar junto ao Departamento de História da Universidade de Yale (1990-91) e como Fellow da Fundaçāo Tinker-Lampadia, fomos Visiting Professor nas Universidades de Connecticut $e$ Massachusetts (1991-92). 
6. PIORE, Michael J. Op. cit., p. 3.

7. FERRO, José Roberto. Strangers and Clandestines in America: Brazilian immigrants in the Boston Area. Cambridge, M.I.T. mimeo, p.5.
Segundo Piore "A primeira característica do processo de imigração é que ele parece responder à atração dos países industrializados. Na Europa, muitos governos de fato organizaram programas para deliberadamente recrutar imigrantes e administrar sua permanência. Nos Estados Unidos, o processo é consideravelmente menos institucionalizado, e porque é clandestino, sua exata natureza ainda é relativamente obscura, mas também aqui o fator estratégico para o início da migração e o controle de sua evolução parece ser a busca dos empregadores americanos de novas fontes de trabalho. Segundo, os migrantes parecem vir para ocupar um conjunto distinto de empregos que a força de trabalho nativa recusa aceitar. Terceiro, o migrante inicialmente se vê a si mesmo como um trabalhador temporário e planeja voltar para casa; entretanto, muitos deles não conseguem realizar seus planos e nunca retornam, ou voltam repetidamente para o país industrial, tornando-se membros mais ou menos permanentes da força de trabalho. Quarto, os migrantes parecem ser amplamente desqualificados; tipicamente eles não falam a língua do país hóspede; frequientemente são analfabetos e não escolarizados na sua própria língua; às vezes eles vêm de áreas rurais atrasadas com pequeno contacto com o tipo de ambiente industrializado e urbano onde trabalham e vivem." 6

A citação é longa mas toca em pontos nodais de noções que passaremos a trabalhar e desenvolver melhor ao longo do texto, seja para perceber uma confirmação da teoria ou uma rejeição dela à luz da análise e descrição da experiência brasileira. De imediato, notamos que a quarta característica apontada não cobre o universo total dos migrantes brasileiros, embora uma parte deles possa caber no modelo. Sobre o fluxo Governador Valadares/Boston temos alguns dados: "Há pessoas de todas as idades, origens sociais, ambos os sexos, mas a grande maioria é composta de homens jovens, entre 20 e 25 anos de idade. (...) Sua origem no Brasil é diversa. Encontrei pessoas dos estados de São Paulo, Rio de Janeiro, Santa Catarina, Espírito Santo, Bahia, Rio Grande do Sul, mas a maioria vem do estado de Minas Gerais, particularmente da área de Governador Valadares. " 7

A predominância de mineiros aparece em todos os dados e textos que consultamos, e só essa constatação, bastante interessante, provoca curiosidade. Por que os mineiros migram mais do que os outros brasileiros? Aspectos históricos e tradicionais da cultura de Minas talvez expliquem essa maior propensão de uma comunidade acostumada aos processos migratórios internos. De qualquer forma, Minas e os outros estados citados não constituem as regiões mais atrasadas do Brasil, pelo contrário.

Sobre a atração exercida pelos países mais industrializados, a idéia contraria a noção mais difundida da "expulsão" de força de trabalho pelos países pobres. A migração atende a necessidades estruturais das economias mais desenvolvidas à medida que os salários pagos e as condições de trabalho oferecidas em certos setores do mercado são recusados pelos trabalhadores nativos, muito mais exigentes, organizados, escolarizados e freqüentemente sindicalizados. Os imigrantes parecem ser, no mundo contemporâneo, o "exército industrial de reserva", que no século XIX era encontrado dentro do país industrializado. A ampliação das desigualdades entre regiões, a universalização das comunicações e até o barateamento dos meios de transporte estão relacionados com a ampliação dos processos migratórios de longa distância. $\mathrm{O}$ interesse e a necessidade do empresário americano em contratar trabalhadores imigrantes foi claramente percebido por um de nossos entrevistados: "Se eu e o cozinheiro não fôssemos imigrantes, o restaurante teria que cobrar preços muito mais altos e não agüen- 
taria a concorrência." ${ }^{8}$

Sobre o tipo de emprego ocupado pelos imigrantes maiores esclarecimentos são necessários. O grupo de trabalho do M.I.T., citado acima, considera que o mercado de trabalho das naçōes mais ricas comporta uma dualidade estrutural. O setor secundário é aquele que não exige escolaridade e qualificação profissional e está localizado nas camadas mais baixas da hierarquia salarial e de status social. Os trabalhadores imigrantes normalmente ocupam esse setor, que não atrai os trabalhadores nativos, captados pelo mercado de trabalho primário, não estando, portanto, os imigrantes efetivamente competindo com esses últimos, mas possibilitando maior lucratividade aos empregadores.

O caráter inicialmente temporário da migração, combinado à ocupação do mercado de trabalho secundário, produz características sociais específicas no trabalhador imigrante. Como ele pretende acumular rapidamente e voltar para casa (diferentemente dos imigrantes do século XIX e primeiras décadas deste), o imigrante atual consegue dissociar seu status social do trabalho que executa provisoriamen-

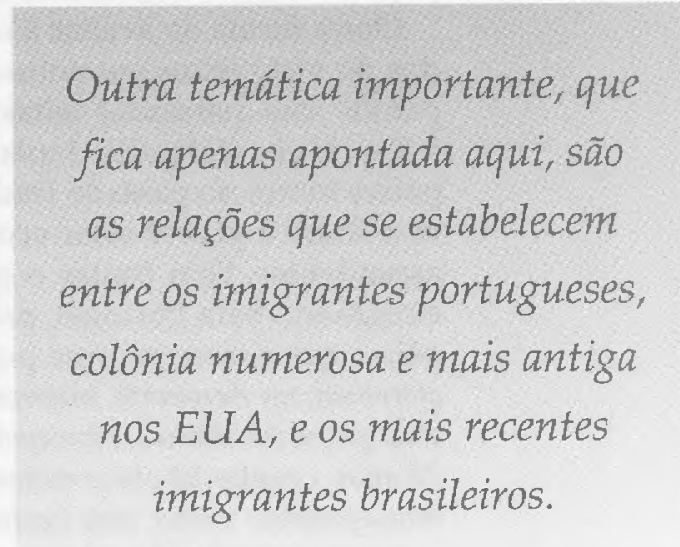
te. Mesmo exercendo funções desqualificadas, por pouco tempo, o migrante tem a sensação de manter o status social do país de origem e consegue manter um ritmo de trabalho superintenso para abreviar a volta. Nessa medida, seria possível dizer que a fixação e a permanência no país receptor configuram o insucesso e a frustração: "Eu sempre quis voltar para o Brasil e montar uma loja de carros usados. Fui trabathando e juntando dinheiro, mas nunca o suficiente para poder voltar. " 9

A transitoriedade da migração precisa ser adequadamente conceituada: "Esse engajamento temporário, entretanto, é ele mesmo transitório. As correntes migratórias que se iniciam como temporárias parecem se desenvolver com o tempo para o estabelecimento de residentes mais ou menos permanente. (...) As tensões e problemas sociais envolvendo a migração estão relacionados com essa transição do estado temporário original." 10

O fluxo Governador Valadares/Boston, por exemplo, é mais antigo do que se pensa. Suas origens parecem remontar à Segunda Guerra Mundial, quando os norte-americanos buscaram a região para abastecer-se de mica, então um componente essencial à fabricação de rádios. Em retribuição, o governo americano ajudou a construir o sistema de água da cidade e contribuiu no combate à malária. Depois da guerra, empresários começaram a freqüentar a região, que se tornou um centro comercial para pedras semipreciosas. Desses primeiros contactos se originaram as migrações, que uma vez iniciadas, são difíceis de interromper, pois as colônias já estabelecidas nos Estados Unidos passam a funcionar como bombas de sucção, trazendo novas ondas de migrantes, estimulados pelo exemplo e pelo chamamento dos já estabelecidos.

Mensurar o processo migratório brasileiro é muito difícil porque os estudos são raros e o caráter clandestino dos migrantes dificulta enormemente a avaliação. Vamos recorrer a algumas estimativas feitas a partir de procedimentos imprecisos e aproximativos. Uma das principais tentativas nesse sentido foi feita pela revista Veja, em re-
8. W.A., pizza man de um restaurante da Nova Inglaterra, vivenda há três anos nos EUA. Paulistano, 32 anos, formado em curso técnico na Mackenzie e pequeno empresário no Brasil.

9. José Pelissari, 51 anos, capixaba, operário qualificado numa metalúrgica. Vive nos EUA desde 1964, entrou como imigrante legal e tem o green card, isto é, o visto de permanência.

10. PIORE, Michael J. Op. cit. p.60. 
11. "Estados Unidos e Japāo são a 'terra da promissão' para muitos que vão tirar o passaporte. 0 número de pedidos de visto de entrada, nestes países, aumenta a cada ano. No consulado japonês de São Paulo, po exemplo, foram emitidos 8,6 mil vistos em 1988 e $33,8 \mathrm{mi}$ até agosto passado. No consulado dos Estados Unidos em São Paulo, que também atende Paraná e Mato Grosso do Sul, a emissāo passou de $95,7 \mathrm{mil}$, entre outubro de 1988 e setembro de 1989, para 110,4 mil de outubro de 89 a setembro deste ano". Fonte: Folha de São Pau10,4 de novembro de $1990, p$ C-3.

12. REVISTA VEJA. São Paulo, Editora Abril S.A., 20(11):38, 16/03/1988.

13. REVISTA VEJA. São Paulo, Editora Abril S.A., 23(3):40, 24/01/1990 portagem especial publicada na edição de 16 de março de 1988, que calcula a partir de estatísticas da Polícia Federal, que entre 1985 e 1988 aproximadamente 1.200 .000 brasileiros deixaram o país sem retornar. Esses números são bastante significativos se considerarmos que eles se aproximam de $1 \%$ da população brasileira no período.

O consulado brasileiro em New York avalia por alto em 70.000 o número de brasileiros vivendo só na região de Boston. Mas esses números não coincidem com as estimativas de José Roberto Ferro que chegam a 100.000 , a partir de informações sobre a existência de três firmas que enviam dinheiro dos migrantes para o Brasil e que têm cada uma delas entre 3 e 4.000 inscritos.

Outra forma de avaliar a revoada tem sido as estatísticas dos pedidos de visto feitos aos consulados e por aqui sabe-se da enorme expansão das demandas feitas para os Estados Unidos; Canadá, Austrália, Nova Zelândia, Japão, Espanha e Itália ${ }^{11}$. Esses últimos três países foram no passado tradicionais exportadores de emigrantes para o Brasil e parece estar ocorrendo uma volta ancestral à pátria dos ascendentes. Sem contar o grande número de brasileiros que estão emigrando para Portugal, país hoje integrante da Comunidade Européia e que exerce enorme poder de atração: "Do avião que acabara de aterrissar no Aeroporto Internacional da Portela, procedente de São Paulo, emergiram devidamente encapotados Sérgio e Vânia Carrasqueira, ambos de 28 anos, casados há cinco meses. 'Eu estava frustrado no Brasil. Tinha uma renda familiar média, mas nenhum horizonte à vista. Eu ia ao supermercado com uma máquina de calcular no bolso, andava nas ruas com receio de assaltos. A impressão que tenho é que estou mudando para um país mais sério' explicou Sérgio ao desembarcar. Ele não foi o primeiro e certamente não será o último: quase 12.000 brasileiros desembarcaram de mala e cuia em Portugal, desde 1980, em busca de algo." 12

Notícias mais recentes descrevem o caminho de volta para o Japão: "O consulado japonês em São Paulo estima que haja atualmente entre 30.000 e 40.000 brasileiros no Japão, onde desempenham funções que a população local apelidou de 'trabalho 3 ki-kitanai, kiken e kitsui - ou sujo, perigoso e pesado. Funções que os próprios japoneses, em sua atual fase de prosperidade, já não querem mais desempenhar. Mesmo na ilegalidade - a rigorosa legislação japonesa proibe a contratação de mão-de-obra desqualificada - a maioria desses emigrantes temporários parte para o Japão disposta a permanecer trabalhando até dois anos como operários em empresas de pequeno porte, geralmente fábricas de autopeças. " ${ }^{13}$ As características desse fluxo para o Japão parecem se enquadrar perfeitamente ao modelo teórico traçado pelo grupo do M.I.T. Quanto às quantias remetidas ao Brasil por esse grupo, estima-se que elas atinjam os $\mathbf{4 0}$ milhões de dólares por mês.

A maior comunidade de brasileiros nos EUA está no eixo New York/New Jersey e está aumentando sensivelmente nos últimos anos. Uma das formas de medir o crescimento é o número de assinaturas de jornais brasileiros que a loja Coisa Nossa (localizada na rua 46, entre a $5^{a}$ e $6^{a}$ avenidas, bem no coração de Manhattan, e situada no "quarteirão brasileiro" da cidade) vende à comunidade: 8.000 assinaturas contra 1.500 há cerca de um ano atrás. A loja existe há nove anos e vem atendendo a uma demanda crescente por produtos brasileiros, especialmente alimentos (farinha de mandioca e milho, leite condensado, pimentas, guaraná, caldo de cana, e até quibe e esfiha, hoje já incorporados à culinária paulista), revistas e jornais. $\mathrm{O}$ aumento da demanda levou à expansão do negócio, que abriu filiais em Newark (New Jersey) e Queens, bairro de New York. 
O aumento da presença latino-americana nessa região e a diminuição percentual da população branca não hispânica foi constatada no censo de 1990: "Demógrafos atribuíram o crescimento da cidade de Nova York primeiramente a mais nascimentos e novos imigrantes.(...) O Census Bureau também liberou dados sobre a composição racial de New Jersey, mostrando que a porcentagem da população branca não hispânica do estado em 1990 era de $79.3 \%$, inferior aos $83.2 \%$ de 1980 . O maior crescimento foi registrado entre os hispânicos, cujo número aumentou de $491.883 \mathrm{em} 1980$ para 739.861 , ou $9,6 \%$ da populą̧ão de New Jersey. " ${ }^{14}$ Esses números confirmam realidades perceptiveis a olho nu, a condição e a cara de terceiro mundo que New York vem assumindo crescentemente, e o fato de que a cidade está se tornando bilíngüe e multirracial, assim como outros núcleos populacionais dentro dos Estados Unidos. Estão se multiplicando as "ilhas de pobreza", especialmente nas maiores cidades americanas e depois de oito anos de grande crescimento econômico a pobreza urbana permanece como um problema insolúvel e cada vez mais grave. ${ }^{15}$ Carên-

A comparação com o México nos
parece salutar, porém sem esquecer
que algumas das diferenças apontadas,
que se aplicam aos brasileiros,
estão relacionadas a um aspecto
geográfico, ou seja, a distância
muito maior do Brasil em relação
aos Estados Unidos.
cias habitacionais, educacionais, sanitárias e de saúde, somadas à expansão das drogas e da AIDS, desafiam permanentemente a Great Society. É nessas ilhas que vive a maioria dos imigrantes brasileiros: "Claudemir, 23, solteiro, muito magro, vive em East Boston com outros seis jovens brasileiros num apartamento de três ambientes. Todos os dias às seis da manhã. uma perua vem buscá-lo para pintar casas. O seu patrão português, proprietário de uma pequena companhia composta dele mesmo, seu fitho e uma média de mais quatro trabalhadores também trabalha com eles e impõe um ritmo muito acelerado para o trabalho. Ele está ganhando \$7.50 por hora, mas está esperando um aumento para breve. Usualmente, chega ern casa às nove horas da noite e tem sorte quando acha qualquer resto de comida para jantar. Ultimamente, isso tem sido raro porque tem havido brigas na distribuição das despesas de comida." 16

Os brasileiros nos EUA freqüentemente são considerados ou assimilados ao grupo mais inclusivo dos "hispânicos", especialmente quando não são brancos. Dessa forma, participam de um grupo social pobre, deseducado e discriminado, mas incluído no rol das mazelas sociais que a sociedade americana tenta resolver. Quando são brancos e mais escolarizados, enfrentam o problema adicional de não participar de nenhuma comunidade socialmente reconhecida: "Não me sinto parte de grupo nenhum aqui. Não sou mexicano, não sou para fazer qualquer coisa. Sou mais qualificado que o mexicano. Sou um caso à parte." 17

Outra temática importante, que fica apenas apontada aqui, são as relações que se estabelecem entre os imigrantes portugueses, colônia numerosa e mais antiga nos EUA, e os mais recentes imigrantes brasileiros. Os dados demonstram que a identidade lingüística e cultural os aproxima freqüentemente, sendo que os portugueses - em geral já estabelecidos e adaptados - exercem o papel de protetores/exploradores para muitos brasileiros recém-chegados. É o caso de Claudemir, citado acima, e muitos outros. A imigração de José Pelissari tam-
14. THE NEW York Times. "Census Revised: New York city Grew in 1980's". 25/01/1991, p.B4.

15. Os recentes riots de South Central Los Angeles foram um importante sintoma dessa problemática.

16. FERRO, José Roberto. Op. cit., p.3.

17. Entrevista com L.R.M., 23, paulistano, curso colegial completo, descendente de italianos dos lados paterno e materno, chegou nos Estados Unidos em agosto de 1989 para ficar seis meses. Trabalha desde entāo num restaurante, onde está sendo promovido a cozinheiro. 
18. FOLHA DE São Paulo. 04/11/1990, p.C3.

19. LAMOUNIER, Bolivar (Organizador). De Geisel a Collor: o balanço da transiçāo. São Paulo, Editora Sumaré/CNPq, 1990, p.15. bém se originou das relações com um cunhado português, que foi o primeiro da família a buscar uma vida melhor nos EUA, levando em seguida vários parentes.

Até agora nos referimos à emigração brasileira para os países receptores mais conhecidos, mas é preciso notar que os migrantes também estão procurando outras regiões: "O advogado Rubens Penteado Manente, 30, pretende se mudar para a Dinamarca no início do próximo ano, com a mulher, a brasileira-dinamarquesa Karen, 25 anos. 'Estou cansado de viver no Brasil. A situação é instável, não se pode ter uma programação de vida. Não dá para ter confiança na situação econômica do país, nem no governo. A casa de meu vizinho já foi assaltada três vezes', diz ele que mora no Brooklin." ${ }^{18} \mathrm{Em}$ outro extremo do mundo, a emigração de brasileiros está preocupando o governo francês, pois chegam cada vez mais brasileiros à Guiana Francesa. Dos aproximadamente 8.000 que vivem hoje em Caiena, apenas 2.950 estão com a situação regularizada e os outros correm o risco de expulsão.

Países tão diferentes como a Dinamarca e a Guiana Francesa estão atraindo os brasileiros que estão radicalmente insatisfeitos com a situação econômica e política do Brasil, percebendo-se que os sucessivos desencantos dos anos 80 e o declínio crescente da legitimidade governamental levaram a uma profunda crise de confiança nas possibilidades do país: recessão de 81-83; frustração com o insucesso da campanha das "diretas-já"; morte trágica de Tancredo Neves; insucesso do Plano Cruzado que despertara tantas esperanças; hiperinflação e crise de governabilidade no governo Sarney, seguidas da estagflação no governo Collor. "Uma descrição persuasiva dos anos 80, com efeito, é que o potencial de conflito social aumentou significativamente, num momento em que a capacidade dos sistemas econômico e politico para acomodar tais tensões decrescia de maneira não menos acentuada.(...) $O$ ponto que estamos destacando, entretanto, é que o aumento e o caráter fortemente corporativo da participação intensificaram as demandas e pressões sociais num momento em que eram declinantes a capacidade decisória do sistema político e a capacidade de acomodação do sistema econômico. " 19

Nunca antes o país enfrentou período tão longo sem crescimento econômico, combinado a um aumento desordenado das demandas sociais, contidas anteriormente pelo autoritarismo do regime militar. Paradoxalmente, a própria democratização liberou a pressão social contida sem ter condições econômicas e políticas de atendê-las. Uma das conseqüências tem sido a emigração dos brasileiros, cada vez mais descrentes e céticos quanto às perspectivas de futuro. A chamada "Nova República" constituiu uma sucessão de fracassos, tanto no combate à inflação, quanto na promoção do desenvolvimento e da distribuição de renda: Plano Cruzado, Plano Bresser, "Política do feijão com arroz", e Plano Verão, sucessivamente despertando esperanças e frustrando as expectativas da população.

Muitos depoimentos de imigrantes brasileiros acentuam essa frustração, especialmente com o Plano Cruzado: "Quando, no final de novembro de 1986, o então Ministro da Fazenda Dilson Funaro admitiu o fracasso do Plano Cruzado e anunciou sem cerimônias o pacote do Cruzado II, José Luiz Nascimento, um químico da Oxiteno S.A., de São Paulo, resolveu que não queria mais ser desrespeitado como cidadão. Recém-casado com $\mathrm{Ci}$ lene, uma psicóloga de 27 anos, José Luiz chamou-a para um almoço. Decidiram, naquele mesmo dia, deixar tudo para trás - dois bons empregos, um apartamento em São Caetano do Sul, suas famílias e seus amigos. 'Nós nos sentimos lesados, como se não estivéssemos sendo levados a sério no Brasil', lembra Cilene. Menos de um ano depois, em outubro de 1987, José Luiz e 
Cilene chegavam ao Canadá com vistos de imigração, três malas e uma poupança de 10.000 dólares para sobreviver nos primeiros anos. "20

A combinação de uma profunda crise econômica, diferente das anteriores pela sua duração (o Brasil, apesar de crises conjunturais, sofreu um intenso processo de desenvolvimento a partir dos anos $30 \mathrm{e}$ até o fim dos anos 70) a uma crise político-institucional grave, em parte decorrente da redemocratização, a uma ampliação rápida e desordenada da mobilização social, produziram na sociedade brasileira uma insatisfaçāo radical, dificilmente encontrável em outras conjunturas históricas e que no nosso entender explica o atual processo migratório.

Simultaneamente à crise brasileira dos anos 80, a América do Norte vivia um período de expansão e otimismo, que vem sendo denominado era Reagan, e consideramos que a conjugação da crise brasileira com a expansão americana tem algo a ver com esse fenômeno migratório sem precedentes na nossa história. As relações Brasil-Estados Unidos configuram hoje traços semelhantes ao antigo vínculo colônia-metrópole, especialmente do ponto de vista cultural, e assim como em outros tempos ex-colonos procuraram e foram atraídos por suas Metrópoles, "colonos" brasileiros vêm sendo crescentemente atraidos pelos Estados Unidos. $O$ fato de que já existiam comunidades brasileiras nesse país favoreceu e estimulou a continuidade e ampliação da migração, pois a existência de núcleos anteriores funciona como uma bomba de sucção, atuando contínua e cumulativamente.

Além de todos esses fatores julgamos que mudanças ocorridas na política de imigração americana também favoreceram a ampliação do fenômeno na segunda metade da década: em 1986, o Immigration Reform and Control Act estabeleceu dois programas de anistia para estrangeiros ilegais, abrindo novas possibilidades de permanência. Mais de três milhōes de imigrantes solicitaram legalização e as conseqüências da lei continuam atuando já que muitos dos que solicitaram permanência temporária naquela época, adquiriram hoje o direito de se tornarem residentes definitivos.

Convém assinalar que a nova legislação é contemporânea do fim do regime militar brasileiro e início da Nova República, conjuntura histórica que, pelas razões arroladas acima, gerou novas ondas de migrantes brasileiros. Nossa hipótese é a de que há uma coincidência de fatores que, tanto no Brasil, quanto nos EUA, propiciaram uma enorme ampliação da migração na segunda metade da década de 80 .

Apesar de que retomaremos a análise da política imigratória norte-americana, é importante adiantar que, historicamente, nos períodos de expansão econômica, o INS minimizou sua ação repressiva e tolerou os imigrantes ilegais: "Como muitos scholars apontaram, nossa politica para com os imigrantes mexicanos variou muto de acordo com os ciclos econômicos e com as necessidades de algumas indústrias americanas em particular. Logo, a imigração era ignorada nos anos 20 e a Segunda Guerra Mundial e o boom do pós-guerra. Mas, a politica se reverteu, freqüentemente de uma maneira brutal e repressiva,

20. REVISTA VEJA. São Paulo, Editora Abril S.A., 23(3):40, 24/01/1990. 
21. PIORE, Michael. Op. cit., p.177.

22. PIORE, Michael. Idem, ibidem, p. 180 nos anos 30 e na recessão pós-Coréia." ${ }^{21}$

A "omissão" do INS certamente facilitou a vida de um dos nossos entrevistados, W.A., que junto com muitos outros brasileiros resolveu emigrar na época da falência do Plano Cruzado. Chegando nos EUA, casou-se com uma americana (brasileira naturalizada) e adquiriu o direito de ter o green card através do casamento, recurso a que muitos outros recorreram. Depois do início da recessão americana, o INS passou a fiscalizar com muito mais atenção os casamentos que poderiam implicar nesse tipo de estratagema de obtenção do green card.

O maior grau de "brancura" de muitos brasileiros (vantagem comparativa respeitável numa sociedade racista como a americana), assim como o maior nível de qualificação, parecem diferenciá-los do maior contingente de imigrantes latino-americanos, isto é, os mexicanos: "Migrantes de outros lugares do hemisfério vão para casa menos frequientemente do que os mexicanos (cada 32 meses); uma porcentagem maior tem família nos Estados Unidos (28\% tinham cônjuge nos Estados Unidos); eles mandam menos dinheiro de volta para seu lugar de origem e avançaram mais na hierarquia ocupacional para posiçōes competitivas com os trabalhadores nativos. " 22

A comparação com o México nos parece salutar, porém sem esquecer que algumas das diferenças apontadas, que se aplicam aos brasileiros, estão relacionadas a um aspecto geográfico, ou seja, a distância muito maior do Brasil em relação aos Estados Unidos. Os mexicanos podem muito mais facilmente entrar e sair dos EUA do que os brasileiros. Assim como o Brasil, no entanto, o México é um país subdesenvolvido/industrializado e os estudos comparativos deverão trazer benefícios para a análise de ambos os processos.

\section{DESCRIÇÃO DE DOIS CASOS}

Tosé Adriano Pelissari nasceu em 3 de outubro de 1940 nuJ ma fazenda do município de Castelo, Espírito Santo, a aproximadamente 300 quilômetros da cidade do Rio de Janeiro. É o caçula de uma família de quatro irmãos, cujo pai era alfaiate e a mãe trabalhava na Santa Casa para complementar o orçamento familiar.

Infância de menino pobre que precisou trabalhar para "ajudar em casa" desde muito cedo - foi carregador, quebrador de pedra, engraxate etc. Também foi coroinha, e a ligação com a Igreja, sua madrinha e protetora, determinou sua vida, possibilitando um processo de mobilidade social ascendente. Passou seis anos num seminário, onde teve acesso ao curso ginasial, e trabalhou para os padres agostinianos na Igreja de São Januário em Castelo. Era um "pau-para-toda-obra", que morava e comia na paróquia, recebendo pequena remuneração de meio salário mínimo, mas tendo como compensaçāo a chance de estudar contabilidade. Formou-se em 1962 e conseguiu um cargo administrativo no setor de importação de peças da companhia aérea Cruzeiro do Sul. "Zé" já tinha progredido na vida, mas achava que era pouco. Não tinha ainda um ano na empresa, quando uma irmã que emigrara para os Estados Unidos em 1962 começou a 
chamá-lo para a "terra da promissão". A migração de Maria Priscilla ocorreu pelo casamento com um português, alfaiate como o sogro, e que resolvera tentar a vida nos Estados Unidos, como muitos de seus conterrâneos. Portanto, no caso do Zé, a migraçăo está ligada a relações de parentesco com a comunidade portuguesa, tradicional fornecedora de emigrantes. ${ }^{23}$ Insatisfeito com o salário, e tendo "familia na América", Zé desembarcou nos Estados Unidos em agosto de 1964, hospedou-se na casa da irmã em New Haven, Connecticut, e com a ajuda do cunhado foi trabalhar na construção civil, onde passou a receber US\$ 3.95 por hora de trabalho. É óbvio que diminuiu o status social, assim como aumentou a conta bancária.

Segundo o depoimento de Zé, o salário mínimo da época era de US\$ 1.25 e o diferencial positivo de seu salário era devido à enorme força do sindicato da catego-

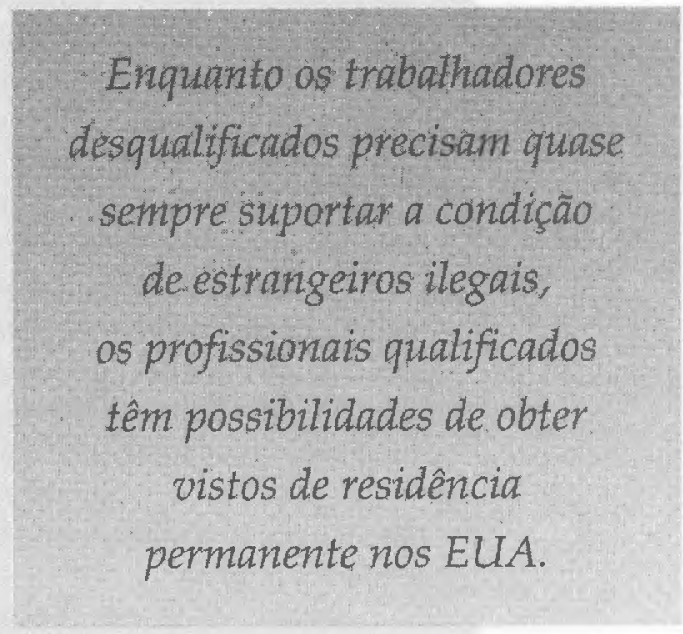
ria. (Hoje, o salário mínimo dos trabalhadores da construção civil estaria em torno de US\$ 15 , enquanto o mínimo do estado de Connecticut perfaz US\$ 4.25.) Era um imigrante legal, que já chegou aos EUA com o green card, pois na época era permitida a imigração de latino-americanos. Passou os seis primeiros anos com empregos temporários no mesmo setor, e o Labor Construction Workers o ajudou sempre a permanecer empregado e com salário alto.

$O$ acesso de José Adriano ao setor da construção civil constitui uma exceção, pois, segundo Piore: "Numa boa parte dos Estados Unidos, entretanto, os trabalhadores da construção civil säo a aristocracia dos blue collars; posiçōes são reservadas para os trabalhadores nativos, e as minorias, que incluem as populações migrantes, foram cuidadosamente excluidas. Aqui deve-se atribuir a diferença à força das organizaçōes sindicais nos Estados Unidos, que manteve um salário relativo muito mais alto e impôs uma organização do trabalho que torna dificil diminuir as habilidades e empregar a força de trabalho imigrante menos qualificada. ${ }^{24}$

Casou-se em 1966 com uma operária brasileira, Marlis, catarinense, filha de alemães, que emigrara para os Estados Unidos com a família alguns anos antes. Tiveram um casal de filhos, Alexander (1967) e Christina (1974) e trabalharam muito, mantendo uma vida frugal e poupando cada centavo para.acumular um patrimônio. Montaram estratégias bastante eficientes de organização da vida com o objetivo de acumular e investir, tal como trabalhar em turnos diferentes para possibilitar a divisão do trabalho doméstico e o cuidado com os filhos, o que permitiu economizar recursos que teriam sido gastos, principalmente na criação dos filhos.

23. Existe uma enorme e bem estabelecida coiônia portuguesa em Providence, capital do esta. do de Rhode Island, que fol estudada pela soclóloga Bellá Feldman. De uma maneira geral, na Nova Inglaterra, existem inúmeros núcleos de colonizaçāo portuguesa.

24. PIORE, Michael. Op. cit., p.18. 
25. Nota da Redaçãa: CD - certificado de depósito bancário.

26. Entrevista com José Pelissari.

27. Entrevista com José Pelissari.
Depois de seis anos na construção civil, setor que remunera melhor mas é muito instável, pois os contratos sāo temporários, José tornou-se operário de uma fábrica de pneus e até hoje trabalha na linha de montagem. Durante seis anos trabalhou na famosa Winchester, empresa que fabrica armas, setor industrial super desenvolvido no estado. Desde 1982 é funcionário da Turbine Company, que opera na manutenção e reparo de peças de avião, trabalhando no período noturno, que paga um adicional de $10 \%$. A esposa é hoje supervisora na mesma fábrica e ganha um salário superior ao do marido: "o trabalhador americano em geral é preguiçoso e não tem ambição. É muito melhor dirigir os imigrantes, que trabalham duro e querem produzir mais, para ganhar melhor." Marlis é hoje cidadã americana, católica militante e eleitora do Partido Republicano, compartilhando com o marido, que permanece cidadão brasileiro, posições políticas bastante conservadoras.

O casal conseguiu amealhar um "pé de meia" e vive hoje na pequena cidade de Brandford, num subúrbio de classe média, numa casa que adquiriram por US\$210.000. Alexander é formado em Psicologia e Christina faz o primeiro grau na excelente escola pública do município, mas mantém a tradição familiar da poupança e do trabalho e já ganha o próprio dinheiro trabalhando como caixa num grande supermercado da região.

Apesar de terem "subido na vida" e gozarem de um padrão de classe média, os Pelissari não estão muito satisfeitos e alimentam o sonho de voltar para o Brasil: "Quero me aposentar e não posso, porque não tenho capital suficiente. Os juros estão baixos. No tempo do Carter os juros eram $16 \%$ (CD ${ }^{25}$ e agora está mais ou menos $7 \%$ ao ano. Pelo que trabalhei deveria ter mais (...) Voltaria para o Brasil, só se fosse para viver de renda. Jamais voltaria para trabalhar. O Brasil é meu país de nascença. É o mellhor país do mundo. $\hat{E}$ um bom pozo. Acolhedor. Sou filho coruja $e$ gosto do Brasil." 26

Os hábitos do Zé revelam uma manutenção de padrões brasileiros: faz comida à moda brasileira (consegue comprar farinhas, temperos e outros ingredientes nas lojas de comerciantes portugueses), assiste futebol nos domingos à tarde (há um canal de cable latino que transmite futebol) não gosta de frio e ouve música sertaneja: "Em 90 quis mudar pra Flórida, porque é parecido com o Brasil. É quente, temt abacate, mangas, praia e turismo. Casas mais baratas. Lembra o Brasil. Nāo mudei por causa da Christina que ia bem na escola. Tinha amigas. " 27

Marlis é muito mais integrada à vida americana, fala português com um ligeiro sotaque e optou pela cidadania americana, mas participa dos planos de voltar e valoriza o "jeito brasileiro de viver", embora seja plenamente adaptada ao american way of life. A adoção da cidadania norte-americana, e a consequiente obrigatoriedade de abandonar a brasileira, fazem parte da estratégia do casal para manter vínculos simultaneamente no Brasil e nos EUA. No caso de uma tentativa de volta à pátria, a permanência da esposa americana é garantida pelo marido brasileiro, e no caso de um insucesso da volta ao Brasil, o retorno aos Estados Uni- 
dos é garantido pela situação inversa.

As relaçōes sociais dos Pelissari se dão preferencialmente ao nível da família extensa, pois ambos os cônjuges têm parentes nos Estados Unidos. Os poucos amigos são brasileiros: "Amizade com americano não tem. Não calhou. Não vou discutir nosso futebol com eles. Não sinto afinidade. Não tenho convivência. Não tenho explicação. Sinto-me mais confortável com brasileiro. Conheço a lingua." 28

O casal mantém militância católica e tem valores morais extremamente rígidos e conservadores. Mais uma vez ouçamos o próprio depoimento: "Sou contra lésbicas e homossexuais. Não gosto das demonstrações que fazem. Sou contra freesex (promiscuidade). Sou contra sexo antes do casamento. Coisas liberais no senso moral. Sou contra a eutanásia." 29 Embora não admita o próprio racismo, contrário à religião católica, José prefere os brancos como ele e conta piadas sobre os negros, que considera preguiçosos, incultos e agressivos.

W.A. nasceu em São Paulo em 1960, no bairro de Santama indústria metalúrgica. Completou o segundo grau num curso técnico da Escola Mackenzie e fez várias tentativas de montar um negócio próprio, tendo tido pouca experiência como assalariado: "Sou um homem de vendas e é isso que eu gosto de fazer. No Brasil ern isso que eu fazia, e ainda vou conseguir fazer isso aqui nos Estados Unidos. " ${ }^{30} \mathrm{~A}$ decisāo de emigrar foi tomada na época do Plano Cruzado, quando a CACEX cortou cotas de importação e inviabilizou uma microempresa que W.A. tinha montado com dois sócios. Antes desse insucesso ele já tinha relaçōes comerciais com um brasileiro estabelecido há 15 anos no estado de Connecticut e vinha para os Estados Unidos com muita frequiência desde 1981.

Chegou para se instalar no país em fevereiro de 1988, trazendo algum capital e pensando em utilizar as relações sociais que cultivara nos anos anteriores para estabelecer uma firma de importação de produtos brasileiros "mas não deu certo, porque os preços e a qualidade dos produtos eram incompativeis com o mercado americano. Além disso, a burocracia retardava o envio das mercadorias e a firma faliu. Virei dishwasher $e$ depois pizza man." ${ }^{31}$

Casou-se com uma americana (na verdade brasileira naturalizada) e conseguiu o green card num tempo recorde, separou-se e trouxe a antiga namorada brasileira, L.S., para viver com ele nos EUA, há um ano atrás. Depois de expirado o

28. Entrevista com José Pelissari.

29. Entrevista com José Pelissari.

30. Entrevista com W.A.

31. Entrevista com W.A. 
seu visto, ela está vivendo ilegalmente no país. L. S. era pedagoga no Brasil e aqui tornou-se empregada doméstica, garhando aproximadamente US\$ 15 por hora de trabalho. Ambos estudam inglês e vivem num apartamento alugado em West Haven, têm dois carros e conseguem manter um padrão de vida que, em termos brasileiros, seria de classe média. São bastante consumistas e não têm uma mentalidade de poupança, estando mais ligados à "curtição" da vida do que ao planejamento do futuro.

W.A. tenta o tempo todo ser e parecer americano e recusa violentamente tudo o que se refere ao Brasil: "Meu projeto é ficar para sempre aqui. Se eu não tivesse minha mãe e 2 irmãs lá, eu não voltaria nem para passear. Aqui tenho mais chances. Em qualquer emprego eu mantenho o padrão de vida. A sociedade é completamente diferente. O que importa é fazer dinheiro. Aqui as pessoas não se preocupam com status. As pessoas se vestem mal, mas têm grana."

W. A. se considera diferenciado em relação a outros migrantes latino-americanos, e mesmo em relação à maioria dos brasileiros. Não suportou a vida em comum, partilhando o aluguel de um imóvel, com um casal de mineiros, na época difícil da falência de sua firma. Suas palavras são eloqüentes: " $80 \%$ dos brasileiros são discriminados por causa da língua, 90\% não têm escolaridade no Brasil, por isso para eles é dificil falar inglês. $90 \%$ vêm para juntar uma graninha e voltar. E pouca grana. Conheço muita gente que tem documento e vai voltar. Eles não vivem a América, eles vivem o Brasil aqui."

A experiência cotidiana, no entanto, às vezes é contraditória com o discurso racionalizador de W. Embora declare o tempo todo não se importar com status social, pediu demissão do restaurante e ficou três meses tentando arrumar um emprego mais compativel com sua qualificação brasileira, o que evidentemente não conseguiu. Quando finalmente foi chamado para um cargo desqualificado, aceitou a função de faxineiro numa empresa, no turno da noite, o que lhe garante US $\$ 500$ por semana.

Como pizza man W. ganhava mais do que isso, mas não era registrado e nem funcionário de uma grande empresa, com todos os direitos trabalhistas assegurados, como agora. Apesar da função desvalorizada socialmente, em relação ao emprego anterior, a trajetória é ascendente. A estratégia do migrante é a pretensão de ascender na hierarquia ocupacional da própria empresa.

W. é muito ambicioso e tem grandes esperanças de realizar o sonho americano da ascensão social e do enriquecimento, tendo plena confiança nas possibilidades de que isso venha a ocorrer com ele, apesar da recessão: "Americano não tem nariz empinado. Se eles têm que trabalhar, eles trabalham. A língua é a grande barreira para a integração. Ainda não falo inglès bem. Quando eu falar bem, poderei subir na vida."

W. procura assimilar e cultiva carinhosamente todos os valores da sociedade americana, inclusive na questáo racial. Valoriza muito sua condição de branco e não vê os negros e nem os hispânicos como iguais. Reduz a discriminação de 
que é objeto ao domínio da língua, supondo que o único obstáculo à sua integração é o domínio perfeito do inglês. Faz enorme esforço para incorporar os padrōes culturais e os hábitos locais, inclusive alimentares. Procura se afastar dos brasileiros mais humildes e dos hispânicos e busca o convívio social com os nativos ou os brasileiros bem estabelecidos e adaptados aos Estados Unidos.

\section{CONSIDERAÇŌES FINAIS}

Os dois casos descritos acima se referem a migrantes de camadas médias baixas, e nos permitem, juntamente com os dados apresentados na introdução, tecer algumas considerações iniciais acerca do fluxo migratório de classe média. Não há intenção, e nem possibilidade de generalizações estatísticas, mas apenas a colocação de um tema novo e relevante para as ciências sociais brasileiras, e algumas hipóteses de trabalho para futuras pesquisas na área.

Os dois casos apresentados envolvem gerações diferentes e momentos diversos das histórias americana e brasileira, assim como das relações entre os dois países, mas julgamos perceber um traço comum na experiência desses dois migrantes brasileiros, ou seja, a necessidade de cons-

Os imigrantes mais

pobres, das regiões mais pobres, permanecem no âmbito da migração interna, buscando os estados do sul para melhorar as condições de vida. truir ilusōes que justifiquem e facilitem o penoso processo de adaptação e aculturação no país adotado. Apesar dos contrastes entre os dois migrantes, ambos construíram universos idealizados, na tentativa de atenuar o sofrimento e as dificuldades enfrentadas na integração à sociedade americana.

A mistificação do país de origem, no caso do migrante antigo, assimilado e vitorioso na trajetória ascendente. A idealização do país receptor no caso do imigrante recente e ainda não integrado. O paraíso perdido do Zé é um Brasil que não existe mais e para onde provavelmente ele jamais retornará; o paraíso inalcançado do $W$. só existe nos thrillers da televisão americana. A ilusão é componente essencial do duro processo de adaptação dos migrantes ao país estrangeiro. Construindo imagens fictícias, seja acerca do Brasil, seja acerca dos EUA, é mais fácil vivenciar a exclusão e a discriminação social.

As dificuldades de adaptação vividas pelo Zé são minimizadas pela fantasia permanente da volta ao paraíso tropical, quente e acolhedor. O reino encantado do progresso e da livre iniciativa esconde a dura realidade vivida pelo W., que "está" faxineiro, mas "ée um homem de vendas. A impossibilidade de ser americano reforça a brasilidade relativamente aparente do Zé e a americanidade fictícia do W.. Em ambos os casos, a ficção construída simbolicamente ajuda a sobrevivência no ambiente estranho.

São reiteradas as afirmações que sugerem motivações extra-econômicas impulsionando a migração de classe média. Ausência de proje- 
32. UNITED STATES Immigration Laws. General Information. Washington, Department of Justice, Immigration and Naturalization Service, p.12.

33. REVISTA VEJA. São Paulo, Editora Abril S.A., 20(11):46, $16 / 03 / 1988$.

34. FOLHA DE São Paulo. 04/11/1990, p.C3. to nacional, desejo de estabilidade e segurança, exigências de qualidade de vida que as grandes cidades brasileiras não oferecem, exigências de cidadania que a sociedade brasileira não satisfaz, frustrações e um profundo desencanto com o futuro do Brasil. Os determinantes macrossociais apontados na introdução, específicos da década de 80, são, entretanto, as molas propulsoras fundamentais da migração de classe média.

Porém, enquanto os trabalhadores desqualificados precisam quase sempre suportar a condição de estrangeiros ilegais, os profissionais qualificados têm possibilidades de obter vistos de residência permanente nos EUA, pois são considerados "categorias preferenciais" de imigrantes: "C-Terceira preferência. Membros das profissões ou estrangeiros com excepcional habilidade nas ciências e nas artes.(...) G- Não preferência. Inclui aqueles que obtêm um certificado de trabalho e são colocados numa lista de espera na ordem em que eles obtêm seu certificado." 32

Segundo esses preceitos legais, os estrangeiros qualificados que têm uma habilidade excepcional nas artes e ciências, designação bastante vaga e genérica, que pode incluir muita gente, estão habilitados a permanecer no país. Cientistas, pesquisadores, professores universitários e artistas em geral podem solicitar a permanência através desse critério.

Se do lado do país receptor não há grandes dificuldades para a imigração de profissionais qualificados, do lado do país doador a crise econômica e a estagnação estimulam esse processo. Uma das nossas hipóteses relativas à evasão de profissionais qualificados diz respeito a distorções no sistema educacional brasileiro. Há no Brasil uma longa tradição de reservar porcentagens respeitáveis dos recursos destinados à educação ao terceiro grau. E apesar da crise da universidade (que não é só brasileira) o país continua formando uma grande quantidade de profissionais liberais, cientistas e pesquisadores de alto nível. Mesmo que o mercado de trabalho absorvesse toda essa mão-de-obra, a sua qualificação não vem sendo remunerada satisfatoriamente. $\mathrm{O}$ caso dos médicos é um excelente exemplo de profissionais profundamente insatisfeitos com os níveis salariais deteriorados.

Há um núcleo importante de boas universidades no Brasil e "ilhas de excelência" em muitas áreas do conhecimento, cujos padrões são compatíveis com países do Primeiro Mundo. Só que a sociedade brasileira não está sendo capaz de absorver esses setores melhor treinados e cientes do nosso atraso.

Experiências anteriores nos países desenvolvidos, como bolsistas ou mesmo turistas, permitem a certos setores mais modernos e qualificados das classes médias uma percepção mais nítida do gap entre as condições de vida no Brasil e naqueles países. Em muitos depoimentos que colhemos percebe-se que a consciência das diferenças está na raiz do processo migratório: "Resta o gosto amargo de ver escapulir do Brasil o que o país tem de mais empreendedor, dinâmico e vivo - justamente os cidadãos não anestesiados que, de mala ou mochila nas costas, querem viver a vida." 33

Nessa mesma linha de raciocínio, o sociólogo Leôncio Martins Rodrigues considera a saída de brasileiros para o exterior "uma perda econômica para o país. O emigrante é alguém com mais iniciativa, com mais vontade de progredir." ${ }^{34}$

Em outros casos a migração é resultado da incapacidade econômica dos setores médios para financiar os estudos superiores. É o caso de L.R.M., cuja entrevista já citamos. Excelente aluno durante sua vi- 
da escolar, não conseguiu na primeira tentativa entrar na Medicina USP e a frustração resultante acabou motivando a migração. O fato é que setores mais e menos afluentes das camadas médias estão crescentemente buscando o exterior como alternativa de vida e quanto mais brasileiros migrarem, mais fácil se tornará a migração, não só pelo efeito-demonstração, mas porque formam-se redes de apoio para receber e ajudar os recém-chegados.

Pelos dados que coletamos percebe-se que a emigração de classe média provém preferencialmente dos estados mais desenvolvidos do Brasil. Os migrantes mais pobres, das regiões mais pobres permanecem no âmbito da migração interna, buscando os estados do sul para melhorar as condições de vida. Para um profissional de Teresina, por exemplo, São Paulo já significa uma melhoria significativa.

A questão colocada aqui se refere à diferença de expectativa quanto ao bem-estar, que é socialmente determinada e varia de acordo com o contexto social. A ausência de desenvolvimento e progresso no Brasil está despertando ansiedades que em outros momentos históricos não aconteceram, porque só agora expectativas criadas pelo próprio crescimento das décadas anteriores estão deixando de ser atendidas. A ampliação das desigualdades regionais internas ao Brasil e entre ele e o Primeiro Mundo acarretam essa seqüência encadeada de processos migratórios, do Brasil pobre para o Brasil mais rico e deste para os países centrais.

Para finalizar, levantamos mais algumas interrogações que apenas a continuidade da pesquisa poderá responder. $O$ governo brasileiro reconhece o fenômeno migratório? Que políticas vêm sendo adotadas em relação a ele? Que atitudes toma a diplomacia brasileira? Qual é a atitude do poder público frente à sistemática negação de vistos de entrada aos jovens brasileiros nos EUA? $\square$

\section{BIBLIOGRAFIA SUPLEMENTAR}

01. PIORE, Michael J. Undocumented Workers and United States Immigration Policy. M.I.T, Center for International Studies, Migration and Development Study Group, Working Paper C/77, December 1977.

02. "Alcune note sul dualismo nel mercato de lavoro." In Revista di Economia e Politica Industriale. 19(1), January 1978.

03. NORTH, Davis \& HOUSTON, Marion. The Charateristics and Role of Ilegal Aliensin the US Labor Market: an exploratory study.Washington D.C., Linton, 1976.

04. NELSON, Joan M. Temporary versus Permanent Cityward Migration: causes and consequences. M.I.T., Migration and Development Study Group, Working Paper C/76-14.

05. FRAGOMEN, Austin T. 1976 Amendments to the Immigration and Nationality Act in International Migration Review. 11(1), Spring 1973.

06. GAMIO, Manuel. Mexican Immigration to the United States. New York, Arno Press, 1969. 